\title{
Lacking Entrepreneurship and Small Business Thrust in Business Education in Developing Countries: Case of Bangladesh
}

\author{
Moslehuddin Chowdhury Khaled \\ Associate Professor, Chittagong Independent University, Chittagong, Bangladesh \\ Email: moslehuddin.khaled@ciu.edu.bd \\ DOI: https://doi.org/10.38157/business-perspective-review.v2i1.123
}

Citation: Khaled, M. C. (2020). Lacking Entrepreneurship and Small Business Thrust in Business Education in Developing Countries: Case of Bangladesh. Business Perspective Review 2(1), 61-76. DOI: https://doi.org/10.38157/business-perspectivereview.v2i1.123

\section{Research Article}

\section{Abstract}

Purpose: Business Education is everywhere. But is business and management education modeled mostly in the North American model or corporate business model, suited for a developing country like Bangladesh, where most of the businesses are small businesses? Who teaches what to whom for whom, using what resources, and following what approaches? Is the need for entrepreneurial and small firms being fulfilled by current business education and management graduates? If not, what to improve? Where to start? This article explores these issues and draws a concrete scenario of business education in a developing country like Bangladesh.

Methods: This is an ethnographic reflection of eighteen years of corporate and academic experience. The author consolidates experiences from 'direct observant participation' including observations coming through continuous interactions with other stakeholders. Thus, the 'going native' syndrome has been minimized through peer validation from both industry and academic professionals.

Results: Business education has a gap or mismatch in expectation and orientation. Teachers are recruited fresh out of universities without any exposure to the industry. Research and journal articles by faculties are hardly relevant and read by industry practitioners. Textbooks are foreign, mostly North American, or copycat translations. Graduates are blindly taught theories, and examples of multinationals. Business schools are nurturing this corporate blindness without any homegrown exercise or comprehensive local need analysis. So, industry, particularly, huge and varied SME sectors are not getting 'person-job' fit management graduates with realistic orientation. All know some of it for sure but none knows the entirety. So, the paper also made actionable propositions for all stakeholders - who could do what from their respective positions.

Implications: Current situation of business education in a developing country like Bangladesh is analyzed in detail. To initiate improvement in a meaningful way, all should have a starting big picture consolidation or situation analysis, on which a broad consensus can be developed, and synergistic progress can be made. This study consolidates that big picture of business and management education in one place, and it can be used one of those 
springboards from where stakeholders can take away their imperatives, and also work in collaboration with other actors.

Originality: All issues are partly known and discussed partly, in a range of papers, seminars, and dialogues. But consolidation in one place, drawing a summary of all actors and stakeholders, along with the context they operate, is rare. This paper attempts to do that.

Keywords: Business and Management Education, Management, Entrepreneurship, SME, Enabling Environment, Interventions.

\section{Introduction}

This article is a reflection of business education in Bangladesh with a specific point of entrepreneurship and small business (as a bundle, called SME, small and medium enterprises) 'thrust'. Though the word 'entrepreneurship' may be found in a variety of contexts, here we use it in the sense of small business initiative or 'enterprises' by business graduates. We also used entrepreneurship and small business 'thrust' in the sense of 'developing the mindset of business graduates for taking up jobs in entrepreneurial and or small firms. SME (small and medium enterprise), here used interchangeably with entrepreneurship, consists of around ninety percent (90\%) of all the businesses in Bangladesh. SME sector has many problems in its ecosystem - regulatory environment, access to finance, global competitions, technology, education, and so on. A lot of literature is available on different dimensions of SME problems (Mazzarol \& Reboud, 2014) in a range of developing and emerging countries like Bangladesh (Chowdhury, Azam \& Islam, 2013; Alauddin \& Chowdhury, 2015; Uz Zaman \& Islam, 2011), Nigeria (Abeh, 2017), China (Cunningham \& Rowley, 2010; Lu-sheng, 2006), India (Garg \& Agarwal, 2017; Singh, Khamba \& Nanda 2018; Getahun, 2016; Lahiri \& Banerjee, 2018), and Pakistan (Dar, Ahmed \& Raziq, 2017; Sherazi, Iqbal, Asif, Rehman \& Shah, 2013; Khalique, Isa, \& Nassir Shaari, 2011). All these studies discussed the overall problems of SME in terms of enabling and regulatory environment, management, and financing SMEs, in their respective countries. Hardly any studies dealt with management education and SME fit. Here in this article, we will focus on business education for SME.

On the demand side of SME, owners and managers of these SMEs need management education for themselves, and for their employees, to manage their businesses professionally in the face of local, and global competition. On the supply side, there are more than a hundred public and private universities in Bangladesh offering business and management education. And also there are many governmentfunded and non-government colleges under the National University system offering the same. But there are many questions that come to an inquisitive mind. Is our business and management education is suited for the country context, particularly from small business and entrepreneurship perspective? Who are teaching? Who are learning? And What? On the industry side; is the need for SMEs and sole proprietor, partnership, or family-owned companies, being fulfilled by current business education and management graduates? If not; what to improve? These issues are explored in this article.

\section{Age-Old Debate on Business and Management Education}

The discourses or the debates on business and management education have been around for many decades. This is an age-old debate - what business and management education actually 
consisted of and how much actually it served the businesses, people, and government and whether it can be exported and transplanted successfully from one setting to another (Leavitt, 1957; Cyert \& Dill, 1964; Sayles, 1970; Porter, McKibbin, \& AACSB, 1988; Sahu, 1991; Mutch, 1997; Lowrie \& Willmott, 2009). That means we may find this ongoing debate in all decades, in this form or another.

The discourses or the debates on business and management education can be divided grossly, into three categories:

1. From the viewpoint of whether 'management' itself is a profession like the medical or legal profession, (for example, Khurana, 2010; Mintzberg, 2004)

2. From the viewpoint of whether 'business and management education' as 'curricula' and as 'school' or 'academic units' possess a certain degree of legitimacy and relevance, (for example, Augier, \& March, 2011; Datar, Garvin, \& Cullen, 2010; Bennis \& O'Toole, 2005; Willmott, 1994).

3. From the viewpoint of whether there is anything significant called 'management research' or how much actually relevance is there in management research compared with industry need, (for example, Ghoshal, 2005; Starkey \& Madan, 2001; Pfeffer, \& Fong, 2002; Podolny, 2009.

4. From the viewpoint of whether the business and management education model can be exported or imported from one setting and to another setting in a standardized way, (for example, Leavitt, 1957; Kieser, 2004).

Despite the first impression that these are known issues (India Today, 2016; Forbes, 2012) our literature review shows that systematic observational study is missing in this line of inquiry. There are many sectoral studies related to skill gap in the industry or Human Resource Development (HRD) in general (for example, HR gap of the tourism sector, health sector, etc.), but studies concerning overall gap of business and management education, with particular focus to developing and nurturing 'own business initiative', entrepreneurship, and SME, is not too common.

\section{Objective: Bangladesh and Developing Country Scenario}

Since developing and emerging countries follow the dominant economies of the world, and their knowledge bases, including textbooks, it is understandable that business and management education has not been an exception. If we take Bangladesh as a representative case from among the developing and emerging countries, it is easily observable that the business schools are providing management education based on the American model with American pedagogical resources and approaches. So it cannot be expected that there are entrepreneurship and SME thrusts in the management education landscape. However, in this article, we attempted to draw a concrete scenario of the subject matter in hand.

Interestingly, 'Entrepreneurship' as a course, is available in the 'core curriculum' of almost all business administration programs in Bangladesh. But those are taught with very traditional lecture method, like any other courses in the curricula (Azim, 2011; Azim and Akbar, 2010). Even if it is taught with any 'particular' approach or method different from other courses, two 
things need to be mentioned. One, having one course on Entrepreneurship and or small business is not enough for having any meaningful thrust. And another thing is, the overall curricula and its teaching are so out of context to have been meaningful to have any entrepreneurship thrust. In Entrepreneurship courses, offered at various academic levels in Bangladesh, the course objective is achieved through teaching 'about' entrepreneurship rather than 'creating' entrepreneurs.

From an overall view to a specific dimension, this article will draw stakeholder's attention to following issues and debates:

- Who are teaching business or management in our universities

- What is being taught; What are the textbooks

- What kind of workplace students are imagining

- Do we need North American or Foreign only degrees to teach in Business schools as the benchmark set by some universities

- In the race of being like North America, what exactly B-Schools are producing and sending in the job market

- On the other hand, who the recruiters are? What are their expectation and the real need

- Are the companies, particularly SMEs, getting the right kind of management graduates that they really need

- What to do in such a situation, who can do what.

\section{Methodology}

The author consolidates both bird's eye view - a general overview of the situation as perceived by different stakeholders, and worm's eye view - direct participant observation in a faculty role in a business school of a private university, located in Chittagong, Bangladesh. In other words, this is an ethnographic reflection of eighteen years of corporate and academic experience. The 'going native' syndrome - seeing only through biased self-perspective, is minimized through peer validation from both industry and academic professionals. This is an otherwise established method in the qualitative research strategy and approach as explained by different methods scholars (Bryman \& Bell, 2011; Saunders \& Thornhill, 2012; Czarniawska, 1998, 2012).

In addition, secondary sources like official websites of relevant institutions, SMEF (Small and Medium Enterprise Foundation), ministry, UGC (University Grants Commission), etc., have been consulted. SME and other policies are reviewed and the current situation of business education analyzed in detail. Stakeholders of business education include students in private university business school, students in public university business faculties, Business faculties of public universities, Business Schools of Private universities, Trustee Board of Private Universities, University Grants Commission, Chambers and Trade Bodies, etc. On different occasions, different stakeholders have been consulted, in a focused way. It has been presented as a keynote paper in different seminars and meetings at different lengths (Khaled, 2016; 2014). Views and comments coming from those sessions have been integrated into the paper, as much as seemed appropriate. 


\section{Historical Development of Business Education in Bangladesh}

In our country, the value of commerce (B.Com / M. Com) started to increase from the late seventies and early eighties when the private sector started to take an increasing role in the overall economy, which was quite in line with the global trend. Earlier business and management education was called commerce education and it was grouped under the faculty of Arts in the department of commerce. Now it is called BBA/MBA almost everywhere in the country.

The first university in present-day Bangladesh, University of Dhaka, was founded in 1921 and had it in the name of 'Department of Commerce' under Arts Faculty. After a long time, in the late nineteen sixties, Dhaka University created Faculty of Commerce, separating from Arts faculty, having mainly the Department of Accounting, and Department of Management. i Gradually elsewhere, in Rajshahi University and Chittagong University and, and affiliated colleges, departments and faculty of commerce were created and they provided B. Com (bachelor of commerce) and M. Com. (master of commerce) degrees.

IBA (Institute of Business Administration) of Dhaka University started first MBA degree in 1966, under 'a Ford Foundation Financial Assistance Program with the objective of providing professional training to create future business leaders' ${ }^{\text {ii }}$ Thus IBA became the pioneer in the country in transforming then available commerce education into modern business and management education.

Chittagong University started its first BBA degree at the undergraduate level in the country in 1989, upgrading its commerce degree curriculum. iii IBA, University of Dhaka, started a BBA degree at the undergraduate level in 1992. Gradually all other universities followed and converted their traditional commerce degrees to BBA/MBA model.

So it is seen, earlier the degrees had different names like B. Com., M. Com., BBS, MBS, BBA, MBA, etc. Recently, almost all of the public-private universities, including national university colleges, standardized the name of the degree as BBA in the bachelor level, and MBA at the master's level. But who is teaching what to whom for what purpose? What are the teaching resources? What industry thinks about teachers, teaching, and teaching materials? What do the students think about their teachers, teaching, materials, and industry relevance? What is the overall current scenario in all these? These are the real questions to understand and explore.

\section{Understanding and Exploring the Business Education Scenario: Bird's Eye View and Worm's Eye View}

Our first task is to have a broad but rigorous understanding of the current situation of business and management education in the country. This can be provided through both Bird's Eye View and Worm's Eye View put together. Bird's Eye View is like a top-down overview which would provide an overall understanding of the situation. And Worm's Eye View is a bottom-up or ground view, which would provide a detailed ground or field-level view of the situation. Being a business school graduate, having some typical corporate experience for a few years, and then moving and being in business school teaching provided the author a better opportunity, compared with an outside foreign consultant, to see from both the bird's and worm's eye view. 
Here are the issues in an exploratory manner.

\subsection{Public and Private - Business education is everywhere}

There are more than fifty (50) public universities and more than a hundred (100) private universities in Bangladesh. ${ }^{\text {iv } ~}$ Public universities are fully funded by the government. Except in a few specialized technical universities like engineering, medical, and agricultural, most of the public universities, including the so-called science and technology universities, have business administration faculty or department and are providing management or commerce degrees. In addition to these, national university colleges and institutes also have business degrees.

Earlier there were some variations of the name of the degree like BBA/BBS/MBA/MBS etc., but as of recently up to 2019, the degrees are commonly called BBA at undergraduate or bachelor level, and MBA at graduate or masters level.

Private university phenomenon started in 1992, according to the Private University Act 1992, revised in 2010. vi And since business education was in high demand, all private universities surely had BBA/MBA in their offerings, regardless of any other degrees. Business and management academic units provided consistent, and more revenue than any other academic units, through tuition fees, which is the only source of revenue for private universities.

Now, at the end of the second decade of the $21^{\text {st }}$ century, both in public and private universities, from Dinajpur to Cox's Bazaar (northern most to southern most region), from Sylhet to Khulna (eastern most to western most region), BBA and MBA degrees are found everywhere, taught everywhere. The reason is market forces. The private-sector industry has grown manifold during the last thirty years or so. The market needs BBA/MBA degrees in a variety of business establishments in many different sectors. Besides, a management degree is increasingly being valued in non-profit sectors and foundations also.

\subsection{Who is teaching: teachers with little orientation to the business world}

The faculty members are recruited fresh out of the universities in the 'lecturer' position. Today's student is becoming tomorrow's teacher just changing the side - from this side of the table facing the black or whiteboard to that side of the table facing the eager young minds. In between, there is no experience and orientation to the business world and 'management education' pedagogy.

In most cases, faculty members themselves did not have enough opportunity in their student life to get an orientation to the business world due to many reasons - lack of resources, access to companies, networking, lack of trust from the business schools and university authority, and so on. So these fresh graduates become lecturer passing the textbook exams and start teaching business from those textbooks and notes, without little orientation to either the business world or pedagogy.

Then they go on teaching for days, and years, due to lack of industry-academy mechanism, gets little opportunity to update with the real-life industry. The recruitment and promotion policies of the universities, do not count corporate experience, and so, a fresh out of the class recruit, is advanced in the teaching hierarchy than someone who got some experience in the corporate 
world and then moved to the teaching profession by choice. So in other words having an orientation to the 'real' world is actually penalized, let alone recognized and rewarded.

\subsection{Where they teach what they teach: North American Knowledge Syndrome}

Business schools exist in every corner of Bangladesh, beyond capital and major cities. Everywhere, it has become very fashionable to promote their programs, with such words as the 'North American' curriculum or 'North-American model'. North American businesses led the world for quite some time. So there must be something to learn and follow. But was there home exercises done on what to adopt' and 'what not to' and 'what to customize'? Should the business education of a developing country follow American texts and knowledge blindly? Without customization? If so, the total arrangement of business and management education serves only a few local subsidiaries of multinationals (MNCs) and a few local big corporate houses or groups of family companies.

Reality is, there are enough lessons to learn from China, Japan, India, South-East Asia, Russia, Brazil, and other countries. More importantly, Bangladesh should create its own knowledge system. More importantly, developing countries like Bangladesh are filled up with small businesses and sole proprietors or family ownership. But there is no effective mechanism from any side, including from university grants commission (UGC) or government, to integrate those realities into the business education curriculum.

\subsection{What are being taught: whose examples and cases}

The textbooks referred are mostly the American like Philip Kotler's Marketing, Ricky Griffin's or Stephen Robbin's Management, Gerry Dessler's Human Resource Management, and so on. The cheap pirated photocopy versions are widely available in the market and those are followed blindly in the business schools. What and whose examples and cases are being taught along with these American textbooks?

These textbooks are popularly filled up with cases and examples, of foreign and big multinationals like Google, Yahoo, Apple, Microsoft, Facebook, Alibaba, Amazon, etc. Earlier when we were students, these were dominated by General Motors (GM), General Electric (GE), Ford, AT\&T, Coca Cola, etc. Some of these books are slightly customized to the Indian market having some Indian company examples. But as a whole, in most cases, the relevance to the local market of Bangladesh seems too little.

\subsection{What do they research and who read them}

As part of the job, faculties write some research articles, whatever, and those are published in their own university journals or elsewhere. Many such university journals do not even have a digital presence, and so cannot be found in any indexed sources. Many such studies and research look very methodical and quantitative but most of them are perception-based statistical problem-solving exercise, rather than the insight of business and industry context of the country.

But the more pertinent issue is who actually read them? Are these business research papers are 
ever read by practitioners in the country, managers of local or foreign companies, big companies, let alone SME owners and managers? Whatever the roundabout answer is, the honest answer is 'No'. There is generally a clear lack of any mechanism where these are shared with the industry and vice versa. No one can give a good number of examples where ideas and suggestions made by these university journals - CU studies, DU studies, are regularly consulted, let alone significantly changed or improved industry and management practice. Some universities and Business Schools invite some popular-face celebrity type managers to their events, and that they repeatedly tout as 'industry-academia' collaboration! So the finding is clear: teachers are either doing typical, perceptual, so-called quantitative research, or researching without effective access to business context, and there is no research communication to their research beneficiaries.

\subsection{Who are being taught - who are the graduates?}

Students in public universities are selected through very selective admission tests. Many of these students at universities of Dhaka, Chittagong, Rajshahi, Sylhet, Khulna, and elsewhere, come from a modest family and economic background, from across the country. Contrary to popular perception, a lot of middle-class family students get into private universities across the countries as there are not enough seats in public universities, which is the very reason the government enabled private universities to grow.

In the case of some rich private universities, they have trustee board members who are established big businesspersons and have connections around. So some of the students of these rich universities are absorbed in MNC or big corporates through connections and some work for their own family companies.

But for the majority of the students, small and local companies are the resorts. These students have little idea of the need, composition, and dynamics of the private sector market place. They also have little connection with the corporate sector. On the other hand, they blindly follow the textbooks, blindly taught by the faculties in the business schools, blindly following North American businesses. In fact, they come to know little about Bangladesh's business environment, regulatory issues, industry scenario, management challenges, and market dynamics. So the students are poorly trained and wrongly oriented and hence, cannot fit and contribute in real life, up to expectation.

\subsection{Who they want to Work for: Only the multinationals and big Corporates}

BBA/MBA graduates want to work for 'structured', 'big', 'reputed' multinational companies (actually local subsidiaries and agent companies), and corporate houses. The belief is they provide a good salary, benefits, and organization structure. There are only a handful of such 'desired' big corporate houses, also called a group of companies, in Bangladesh. Most of their head offices are in Dhaka. Chittagong has some others. So typical 'desired' jobs for BBA/MBA are mostly available in Dhaka and Chittagong.

Apart from Dhaka and Chittagong, other districts or cities are not 'corporate' type yet. SME as a source of knowledge is not yet established. So business schools are everywhere but there are not 
enough 'places', around the country that can serve as 'destination' point for student internships, industry visits, or consultancy by the faculty members.

All the B-schools boast on the fact - how many of their graduates went to work or intern for Unilever, British American Tobacco, Nestle, Citibank N. A., HSBC, Standard Chartered, Grameenphone, Robi, etc. But what is the portion of all these companies together, in overall employment of the management graduates! Very little compared to the total number of BBA/MBA graduates coming out of universities each year. It seems, as if, business education is only for these few MNCs and corporates, whereas we have a huge sector, namely, SME. Most of our companies fall in this latter category, and they are not getting the rightly educated workforce with the right kind of mindset.

\subsection{Bank, Bank, Everywhere: Everyone wants to be a banker}

Another phenomenon developed in and around B-school education is that a major chunk of students wants to work in banks, and hardly consider any other option. The banking sector is one of the largest organized sectors. Most of the students do their internship to fulfill the degree requirement, and banks do easy prey on them by interning them for free most of the time. Thus banks become so visible to the naïve students. People's perception has developed in this way: if $B B A / M B A s$ get a job in a bank where employees can sit around in well-furnished air-conditioned offices then the investment in business education, more so in a private university, is worth it.

This is also another byproduct of the imbalance of the real economy and financial economy. There are acute shortages of examples and cases from the local context and business and industry orientation in the business school curricula. SME and entrepreneurship are totally non-existent. So, that business education has a much larger scope in the 'real' economy, rather than in the financial economy is almost unknown.

\subsection{Disconnected North American Model Private B-schools}

In general, there is a North American syndrome in the business education arena. Some of the rich private universities are even more disconnected. Some first-mover private universities have set a trend recruiting faculty with North-American degrees as much as possible. Even the UK, Australia, Japan, Southeast Asian, or usual European degrees are considered secondary to North America. These universities do not have any research degrees in themselves but ridiculously emphasize foreign only Ph.D. as faculty qualification. Again, they give the foreigneducated faculties a regular load of 4 courses per semester, 12 courses, or more per year. Overall, this is a contradictory position by some business schools.

Following the North American model is good but 'blindness' in faculty recruitment is a hindrance in developing an appropriate 'Bangladesh' model in lieu of a North-American model. Ideally, a good business school in Bangladesh should be open-minded and combine the best of foreign and local degrees, when it comes to developing a faculty pool. And the school should develop foreign exposure of its faculty pool by sending them into conferences and training in foreign institutions.

Some of the leading universities modeled in the North American way can make some good 
connections and focus on serving a few top companies. Even if successful in its own little circle, it cannot be considered a socially responsible behavior for a university. In the overall context of a society, this leads to disconnected elitism, and add to existing inequality and inequity ecosystem.

\subsection{Real market scenario: Demand-Supply mismatch}

Due to the disorientation in the business school education, there is a perennial mismatch between what kind of graduates industry wants, and what they get. The industry is full of local companies and most of them are in the SME sector. Even the large companies are not getting the right personnel, let alone the SME sector which needs a different set of mindset and skill set.

What the industry is getting is a bunch of parrots filled up with irrelevant knowledge and expectations. A more serious problem is these B-school graduates grow up with the wrong imagery of the country's business context and the job market. Local businesses are recruiting MBA's who are frustrated to end up in SME or local companies, and worse, they waste scarce SME resources by job shirking to work for big or MNC.

In summary, it is clear that MSME (micro, small, medium enterprise) sector and entrepreneurial thrust is totally ignored, in the whole business and management education (BBA, MBA, etc.) ecosystem. We can summarize our exploration in the following points:

a. Business education has a huge gap to fill in the ecosystem.

b. Business education is too focused on some MNCs and banks.

c. SME and entrepreneurship is almost fully ignored in the curricula and ecosystem

d. The gap or mismatch is about expectation and orientation

e. Graduates grow up with the wrong imagery of the job market full of lofty multinational environment and big corporates.

f. B-schools, both public and private, are nurturing this corporate blindness and foreign blindness without any homegrown exercise or comprehensive local need analysis.

g. Industry and businesses are not getting rightly oriented management graduates

h. No stakeholders, including the demand side-industry, seems to know how to intervene effectively

i. So here is the gap and we should be in search of intervention points. For a developing country aspiring to progress in industry, business, and commerce, this is long due that an effective process or mechanism that needs to be well established.

\section{Recommendations: The Road Ahead}

Based on our field-level exploration and overall analysis of the situation of Business and management education in the country, here are some general recommendations in this kind of scenario:

A. Acknowledge the Gap: The first step of any problem solving is accepting and recognizing that there is a problem and that there are things to do. All stakeholders and 
actors such as business schools, chambers, and industry associations, and public media need to acknowledge that the goal and purpose of management education cannot be producing management trainees only for a handful of MNC branches in Bangladesh. And that the goal should be to develop management graduates and professionals for a range of varied local industries and SMEs in particular across the countries.

B. What B-School of public universities can do: Public universities are plagued with many other types of inefficiency problems. But they are not in a day to day pressure for generating revenue as in a private university, sometimes touted by many as BBA/MBA degree mills. So business education or academic units in public universities can initiate their own need analysis exercise and connect with local industries. They can develop textbooks, case books, and integrate those in their curricula utilizing their governing autonomy. In this regard fund is available with World Bank HEQEPvii and other donors, as we see the government is heavily biased in favor of public university till now. But first, they need to develop their own consensus and reengineering framework in the faculty or school or department. (Otherwise, HEQEP or donor money will be inefficiently used and wasted).

C. What B-Schools of Private universities can do: Private universities have the limitations of the regulatory environment and enabling environment. Even though, Dean/ Directors or academic leadership can advocate and initiate the process of setting aside a fund and time for local industry research and need analysis (for example, more research and selfdevelopment time for faculty, less teaching load). They can create a bright pool of young faculty and retired practitioners. They can create an enabling environment internally in the organization for industry-based or local SME based research. They can create a dissemination culture to be developed where local businesses and academics are integrated. Faculty and students will thus be able to develop orientation, expectation, and interest in different industries and organizations. To accommodate doing all these localizing and curriculum development, business schools should have an internal consensus to forgo some textbook portions of their North-American curricula. Beyond that, their trustee board approval is customary and they need to be convinced about this.

D. What Trustee Board of Private Universities can do: In the case of private university business schools, the role of the trustee board is instrumental in enabling the environment for faculty and the business school. At least some of them are supposed to be academic minded and should understand that developing Bangladesh context curriculum and education need some time and money (less class and more research and self-development time for faculty members). They also should go for some out of the box thinking and appreciate that current North American text and case blindness to be replaced with an eclectic approach of designing contextually appropriate educational resources. Some trustee board members already know it. Now they need to take their time out for joint exercise with the faculties. They should do it for the sake of the university they founded and for the greater interest of the business and management education of the nation. 
E. What Trustee Board of Private Universities can do: In the case of private university business schools, the role of the trustee board is instrumental in enabling the environment for faculty and the business school. At least some of them are supposed to be academic minded and should understand that developing Bangladesh context curriculum and education need some time and money (less class and more research and self-development time for faculty members). They also should go for some out of the box thinking and appreciate that current North American text and case blindness to be replaced with an eclectic approach of designing contextually appropriate educational resources. Some trustee board members already know it. Now they need to take their time out for joint exercise with the faculties. They should do it for the sake of the university they founded and for the greater interest of the business and management education of the nation.

F. What UGC can do: UGC (University Grants Commission) is the apex body for monitoring and evaluating the public universities and private universities. UGC is responsible for overseeing the government fund allocation to the public universities but can do little in controlling public universities, as they are highly autonomous. On the other hand, paradoxically, UGC, or government do not give any fund to private universities, but control them heavily or enjoys that discretion. Said that UGC, if it wants, can play a significant enabling environment for the business faculty or schools when it comes to the contextualization of the curricula and materials. For example, they can allocate some of the government funds and donor funds for such local industry research, encourage textbooks by local authors, etc. more so in case of private universities who depend fully on tuition revenue.

G. What students can do: Students should not be blind to the imagination that they must work in MNC, big brand corporate, or banks only. They should explore the varied possibility of career development outside a handful of MNCs and banks. They need to develop the mindset that developing their own small business is not anyway secondary to corporate jobs. Yes, ultimately their expectation and orientation will depend on the business school's ability to diversify beyond readymade foreign textbook education and case study. But even then students also should take their own part of the responsibility, thanks to the internet and open wide world. Students should train themselves in varied skills computers and languages rather than waiting or depending on their business schools to tell them to do so. For example, students should learn Arabic, French, Chinese, Spanish, etc., in addition to English, and different aspects of data sciences, big data, artificial intelligence, applications software in accounting, statistics, modeling, etc.

H. What the Chambers and Trade Bodies can do: Business associations like FBCCI, Dhaka chamber, Chittagong Chamber, are in a position to take a proactive role and look for an invention point. Sure, they have their own problems of petty grouping, personal clashes, capsized by few, etc. Nevertheless, they are free from structural limitations faced by public university business faculties and private university business schools. In many cases fund is not a major problem for them. But yes, they need some academic minded 
members in their board who will take the lead for this huge project championing and management. The project includes a comprehensive situation analysis of business education on one side and industry management personnel need analysis on the other. Then they should deploy qualified academicians for developing appropriate curriculum, text, examples, and cases. It may be a full time or project-based assignment. Universities need to provide their faculty free time for this assignment. And finally, these materials developed under this project may be consolidated and disseminated to business schools and to the public in general.

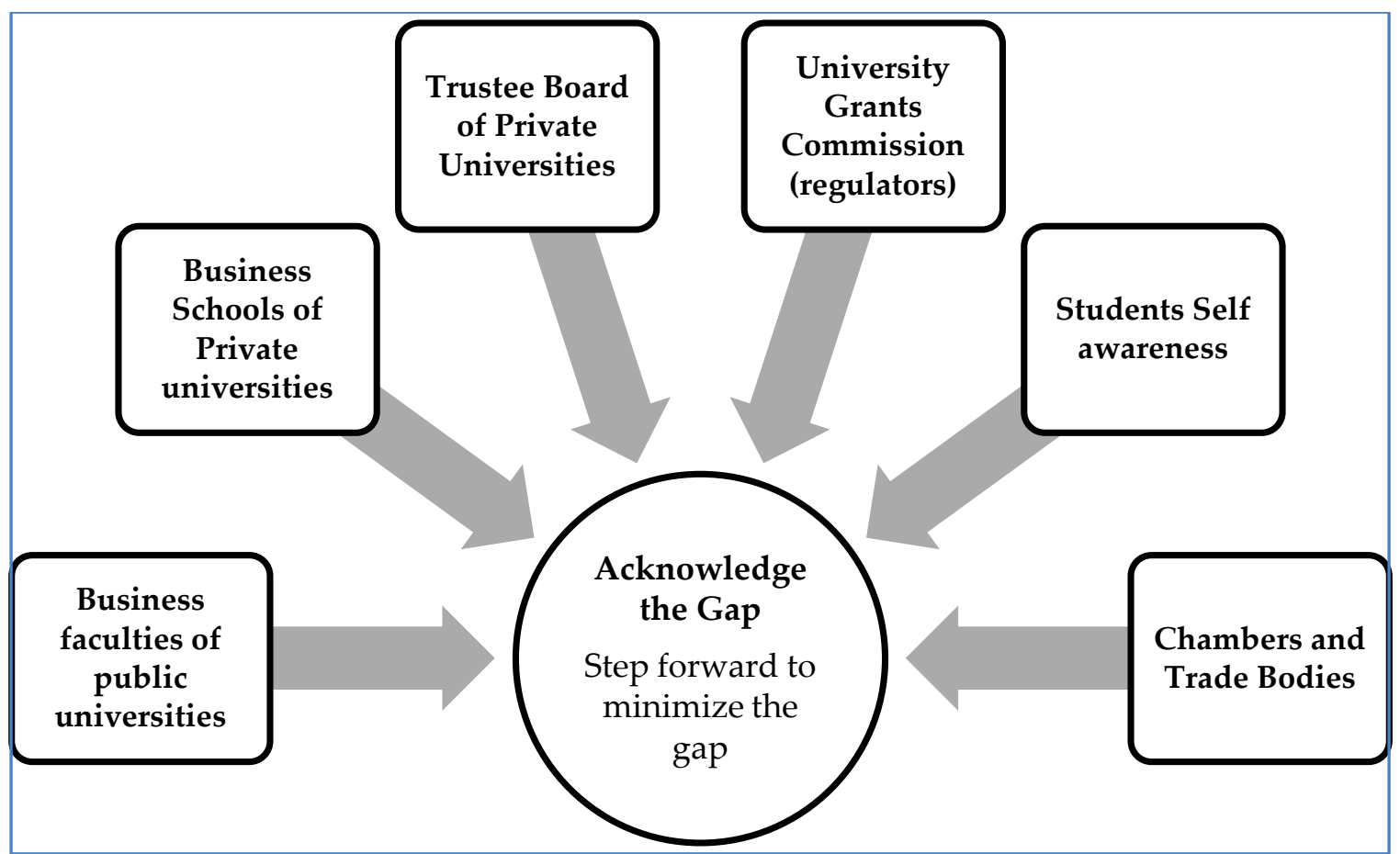

Figure -1 the Business Education Gap and Stakeholders

\section{Conclusion}

This article precisely identified the gaps from a broad perspective. As a whole, these are just general recommendations, and many specific activities can be designed around these. First, all stakeholders need to recognize and acknowledge the gap in business and management education. Though it may seem known, but more understanding and dialogue is needed to design effective and impactful intervention. Future studies may think of this intervention issues and a number of action research may come out of those.

Public universities, private universities, industry sector associations, Chambers, and government all need to have an intensive and iterative dialogue. A concrete action plan needs to be developed to create a whole range of teaching and learning systems and resources suitable for local and SME companies. Chambers and organizations like SME Foundation (a government agency created for SME facilitation) can take a lead or coordinate in this regard. SME Foundation has done some good works but these need to be connected and communicated with the beneficiaries. In addition, any actor may advance from their respective positions rather than 
wait for others to be proactive. But one thing is sure, all stakeholders need to collaborate to a large extent, and continuously.

In conclusion, it may be emphasized that there are many things to do but the first thing to do is agreeing on the very fact that our business and management education needs some overhauling, reforms, rethinking, redesigning, reengineering, etc. - whatever word makes sense of the whole imperative.

\section{Conflicts of Interest: The author declares no conflict of interest.}

\section{REFERENCES}

Alauddin, M. D., \& Chowdhury, M. M. (2015). Small and medium enterprises in Bangladesh-prospects and challenges. Global Journal of Management and Business Research, 15(7).

Augier, M., \& March, J. (2011). The roots, rituals, and rhetorics of change: North American business schools after the Second World War. Stanford University Press.

Azim, M. T., \& Akbar, M. M. (2010). Entrepreneurship education in Bangladesh: A study based on program inputs. South Asian Journal of Management, 17(4), 21-36.

Azim, M. T. (2011). Entrepreneurship development in Bangladesh. Dhaka: University Grants Commission.

Bennis, W. G., \& O'Toole, J. (2005). How business schools have lost their way. Harvard business review, 83(5), 96-104.

Bryman, A., \& Bell, E. (2011). Business research methods. New York: Oxford University Press.

Chowdhury, M. S. A., Azam, M. K. G., \& Islam, S. (2013). Problems and prospects of SME financing in Bangladesh. Asian Business Review, 2(2), 109-116.

Cunningham, L. X., \& Rowley, C. (2010). Small and medium-sized enterprises in China: a literature review, human resource management, and suggestions for further research. Asia Pacific Business Review, 16(3), 319-337.

Cyert, R. M., \& Dill, W. R. (1964). The future of business education. The Journal of Business, 37(3), 221-237.

Czarniawska, B. (1998). Qualitative Research Methods: A narrative approach to organization studies. Thousand Oaks, CA: SAGE

Czarniawska, B. (2012). Organization theory meets anthropology: A story of an encounter. Journal of Business Anthropology, 1(1), 118-140.

Dar, M. S., Ahmed, S., \& Raziq, A. (2017). Small and medium-sized enterprises in Pakistan: Definition and critical issues. Pakistan Business Review, 19(1), 46-70.

Datar, S., Garvin, D. A., \& Cullen, P. G. (2010). Rethinking the MBA: Business Education at a Crossroads. Harvard Business Press.

Datar, S. M., Garvin, D. A., \& Cullen, P. G. (2011). Rethinking the MBA: Business education at a crossroads. Journal of Management Development, 30(5), 451-462.

Garg, S., \& Agarwal, P. (2017). Problems and prospects of woman entrepreneurship-a review of the literature. IOSR Journal of Business and Management, 19(1), 55-60.

Getahun, M. (2016). The challenge and prospects of small scale enterprises in Ethiopia: A survey of some selected small scale enterprises in Addis Ababa city. International Journal of Scientific and Research Publications, 6(5), 617626.

Ghoshal, S. (2005). Bad management theories are destroying good management practices. Academy of Management learning \& education, 4(1), 75-91.

Forbes. (Dec 10, 2012). Growing gap between what business needs and what education provides

India Today. (July 11, 2016). 93 percent MBA graduates are unemployable: Problems with management education in India.

Khaled, M. C. (2016). Family business \& entrepreneurship: transition to corporate business in Bangladesh. Paper presented at 'UGC Chairman and Business community' Seminar, in Chittagong Independent University, September 16, 2016.

Khaled, M. C. (2014). Who teach what to whom and for whom: the gap of business education in Bangladesh?

74 Published by Research \& Innovation Initiative, 3112 Jarvis Ave, Warren, MI 48091, USA 
International Trade Fair Publication 2014, Chittagong Chamber of Commerce \& Industries.

Khalique, M., Isa, A. H. B. M., \& Nassir Shaari, J. A. (2011). Challenges for Pakistani SMEs in a knowledge-based economy. Indus Journal of Management $\mathcal{E}$ Social Sciences, 5(2).

Khurana, R. (2010). From higher aims to hired hands: The social transformation of American business schools and the unfulfilled promise of management as a profession. Princeton university press

Kieser, A. (2004). The Americanization of academic management education in Germany. Journal of Management Inquiry, 13(2), 90-97.

Lahiri, I., \& Banerjee, M. (2018). Brand sustainability and brand development: critical issues for micro, small and medium enterprises in India. International Journal of Entrepreneurship and Innovation Management, 22(3), 298-316.

Lu-sheng, G. Y. F. (2006). Studies on the Problems of SME Supporting Polices System An Empirical Analysis on Shanxi Experience [J]. Economic Management, 18.

Leavitt, H. J. (1957). On the export of American management education. The Journal of Business, 30(3), 153-161.

Lowrie, A., \& Willmott, H. (2009). Accreditation sickness in the consumption of business education: The vacuum in AACSB standard setting. Management Learning, 40(4), 411-420.

Mazzarol, T., \& Reboud, S. (2014, December). Key problems facing SME owner-managers in strategy and innovation: evidence from a diagnostic survey. In the 28th ANZAM Conference. Sydney, Australia (pp. 3-5).

Mintzberg, H. (2004). Managers, not MBAs: A hard look at the soft practice of managing and management development. Berrett-Koehler Publishers

Mutch, A. (1997). Rethinking undergraduate business education: a critical perspective. Management Learning, 28(3), 301-312.

Porter, L. W., McKibbin, L. E., \& American Assembly of Collegiate Schools of Business. (1988).

Pfeffer, J., \& Fong, C. T. (2002). The end of business schools? Less success than meets the eye. Academy of management learning $\mathcal{E}$ education, 1(1), 78-95.

Podolny, J. M. (2009). The buck stops (and starts) at business school. Harvard Business Review, 87(6), 62-67.

Porter, L. W., McKibbin, L. E., \& American Assembly of Collegiate Schools of Business. (1988). Management education and development: Drift or thrust into the 21st century?. New York: McGraw-Hill Book Co.

Saunders, M., Lewis, P., \& Thornhill, A. (2012). Research methods for business students. New Delhi: Dorling Kindersley (India) Pvt. Ltd/Pearson.

Sherazi, S. K., Iqbal, M. Z., Asif, M., Rehman, K., \& Shah, S. H. (2013). Obstacles to small and medium enterprises in Pakistan. Principal component analysis approach. Middle-East Journal of scientific research, 13(10), 1325-1334.

Singh, D., Khamba, J. S., \& Nanda, T. (2018). Problems and prospects of Indian MSMEs: a literature review. International Journal of Business Excellence, 15(2), 129-188.

Starkey, K., \& Madan, P. (2001). Bridging the relevance gap: Aligning stakeholders in the future of management research. British Journal of Management, 12(s1).

Sayles, L. (1970). Whatever happened to management? - or why the dull stepchild?. Business Horizons, 13(2), 25-34.

Sahu, K. (1991). Reorienting management education. Economic and Political Weekly, 26(48), M133-M136.

Starkey, K., \& Madan, P. (2001). Bridging the relevance gap: Aligning stakeholders in the future of management research. British Journal of Management, 12, S3-S26.

Uz Zaman, A. H., \& Islam, M. J. (2011). Small and medium enterprises development in Bangladesh: Problems and prospects. ASA University Review, 5(1), 145-160.

Willmott, H. (1994). Management education: provocations to a debate. Management Learning, 25(1), 105-136

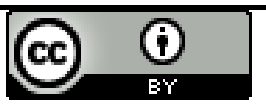

(C) 2020 by the authors. Licensee Research \& Innovation Initiative, Michigan, USA. This article is an open-access article distributed under the terms and conditions of the Creative Commons Attribution (CC BY) license (http://creativecommons.org/licenses/by/4.0/).

\section{Notes}

i Dhaka university Website http://www.du.ac.bd/main_menu/academic/facbusns

ii IBA, DU website: http://iba-du.edu/index.php/page/view/360

75 Published by Research \& Innovation Initiative, 3112 Jarvis Ave, Warren, MI 48091, USA 
iii Chittagong University website: www.cu.ac.bd/ctguni/index.php?option=com_cudata\&task=business administration

iv University Grants Commission website, http://www.ugc.gov.bd/

v Ministry of Education, http://www.moedu.gov.bd/

vi Private University Act 2010

www.moedu.gov.bd/index.php?option=com_content\&task=view\&id=510\&Itemid=400

vii HEQEP stands for Higher Education Quality Enhancement Project of World Bank. UGC is the implementing agency. http://heqep-ugc.gov.bd/index.php/home/About 